\title{
MORPHOLOGICAL AND IMMUNOHISTOCHEMICAL ASSAYS OF SURGICALLY REMOVED MAMMARY GLAND TUMORS IN BITCHES
}

\author{
MAGAŠ V*, JOVIĆ S*, NEŠIĆ $V^{*}$, BACETIĆ $D^{\star *}$ and ALEKSIĆ-KOVAČEVIĆ SANJA* \\ *Faculty of Veterinary Medicine, Belgrade; **School of Medicine, Belgrade
}

\author{
(Received 5. May, 2006)
}

In this study an estimation of the malignancy of mammary gland tumors was carried out based upon clinical examination, macroscopic and pathohistological characteristics of neoplasms and expression of cytokeratins.

In the study 60 bitches of different ages, race and reproductive status with clinically evident signs of mammary gland tumor were included. After clinical examination the mammary gland tumors were excided, after which tissue samples were taken for subsequent pathohistological and immunohistochemical analysis. Tumors are classified according to the latest WHO recommendation (1999). The ratio of malignant tumors vs. non-malignant was $1.9: 1$.

The most frequent malignant tumor was adenocarcinoma $(n=17)$, followed by complex adenocarcinoma $(n=12)$, carcinoma in mixed tumors $(n=5)$, mucinous carcinoma $(n=3)$, and fibrosarcoma and osteosarcoma, one of each. Most common benign changes were benign mixed tumors $(n=10)$ and adenoma $(n=6)$. Hyperplasia of the mammary gland was found in two bitches, while chronic steatitis, fibrosis and complex adenoma were reported only in individual cases.

The expression of cytokeratins on different malignant and benign neoplastic cells was determined by the immunohystochemical peroxidase-antiperoxidase method. In simple carcinoma a positive reaction was established within the epithelium of the lumen of the alveoli and in the stromal tumor cells present in the lymph and blood vessels. In the cells of complex tumors cytokeratin was expressed on epithelial cells as well as on spindle, stellate and myoepithelial cells.

Key words: bitch, mammary gland tumors, pathohistology, cytokeratin

\section{INTRODUCTION}

The study of the problems related to mammary gland tumors is of special interest not only in human, but in veterinary medicine, as well. This being everyday more obvious by the increasing number of experimental studies which are carried out worldwide. Numerous experiments are performed in order to determine 
whether mammary neoplasms in bitches can be viewed as a model of mammary gland tumors in women. Animal models, especially dogs, are often selected due to their short life span and high number of possible focal points (ten mammary complexes), thus making bitches the ideal animal model for such comparative studies (Jelisijevic, 2003).

Tumors of the mammary gland are the second most common tumor following skin tumors in bitches. According to the available data benign and malignant tumors are present with an almost equal incidence. Mammary gland neoplasms are mainly found in "middle aged" bitches, and are seldom diagnosed in bitches younger than 4 years, and are rarely present in males (Alenza et al., 2001; Misdorp, 2002; Novosad, 2003).

The etiology of mammary gland tumors is still unknown, however great attention has been paid to the influence of steroid hormones on tumor genesis. The effect of geographical factors, age, radiation, breed and familiar predisposition, genetic factors, stem cells, viruses, oncogenes and growth factors have been extensively studied (Alenza et al., 2000; Sorenmno et al., 2000; Philibert et al., 2003; Chang et al., 2005; Zatloukal et al., 2005). In order to provide an exact diagnosis pathohistological, immunohistochemical, citochemical and tissue culture procedures are applied. Diagnosis and prognosis of mammary gland neoplasms in bitches, based mainly on routine pathohistological assays, is not always so simple, considering that frequently they are undifferentiated neoplasms and bearing in mind the numerous published histological classifications of tumors (Martin et al., 1998; Mulas et al., 2004; Zuccari et al., 2004; Monteros et al., 2003, 2005).

In the last years the use of antibodies, which are able to mark specific antigens on normal and tumorous cells, is becoming more frequent. It is of great importance to follow up the expression of cytokeratin, vimentin, desmin, actin and S-100 proteins on cell lines originating from healthy and neoplastic mammary glands. The incidence of selected cytoskeletal elements helps in the determination of the histological type of tumor, particularly in cases where the studied cells are atypical.

During the studies which were carried out to determine the expression of the I and II group of intermediate filaments (IF) it was established that cytokeratins are expressed in tumor cells of epithelial origin (Aleksić-Kovačević et al., 2002). In the majority of both benign and malignant tumors myoepithelial cells are an important component. By immunohistochemical assays it was determined that myoepithelial cells transform via proliferating, spindling, changing into stellate and cartilaginous cells and by doing so they change the expression of citoskeletal proteins. In resting and proliferating myoepithelial cells, located on the luminal side of the basal membrane, a positive reaction to cytokeratin 19 , vimentin and $\alpha$ actin was recorded (Griffey et al., 1993). Spindle cells were weakly positive to cytokeratin 19 and $\alpha$-actin, and strongly positive to vimentin and S-protein. Stellate cells showed similar reactivity as spindle cells. The reactivity of chondroblasts was dependant on the degree of their differentiation. On the peripheral zone of the cartilage a weak positive reaction to $\alpha$-actin and cytokeratin was recorded, while in the central zone was evident a strong positive reaction to 
vimentin and S-protein and a negative reaction to cytokeratin 19 (Destexhe et al., 1993; Gartner et al., 1999). In general, all mammary gland fibrosarcomas are positive to vimentin, while adenoma, myoepithelioma, comedocarcinoma, complex carcinoma and osteosarcoma are positive to desmin and cytokeratin. In some of these tumors the expression of neurofilaments was present, as well (Hellemen and Lindgren, 1989).

One of the major setbacks of the application of pathohistological methods is the impossibility to determine accurately the origin of neoplastic cells in the tumorous tissue as they are often poorly differentiated. In our study immunohistochemical assays were performed in order to elucidate the origin of neoplastic cells.

\section{MATERIAL AND METHODS}

The study was carried out on 60 bitches treated at the Faculty of Veterinary Medicine in Belgrade. All bitches displayed clinically evident changes of the mammary gland. The age of the bitches was between 3.5 and 14 years. The breed of the observed bitches was not uniform, as by random choice in the experiment were included 20 mixed breed and 40 pure breed bitches, but of different breeds. The reproductive status of the studied animals was not consistent and it included bitches which did not have a litter, those which had only one litter and those which had two or more litters in their lifetime. From all the bitches, which were included in this research, tissue samples from more than one site of tumorous proliferates were taken surgically in order to obtain an objective estimation of the characteristics of the tumor.

The surgical procedures were carried out on bitches under dissociative anesthesia induced by ketamine $(10-20 \mathrm{mg} / \mathrm{kg})$. In patients which had a well defined tumorous proliferate smaller than $1 \mathrm{~cm}$ nodulectomy was carried out, whilst on patients with mammary tumors larger than $1 \mathrm{~cm}$, with unclear margins a partial or complete mastectomy was performed. Cases, which involved the IV or V mammary complex, underwent complete mastectomy and extirpation of inguinal lymph nodes.

Tissue samples were fixed in $10 \%$ neutral formalin for 48 hours. For immunohistochemical studies the peroxidase-antiperoxidase (PAP) method was applied. Slices $5 \mu \mathrm{m}$ thick were deparaffinised in xylol and rehydrated in a series of alcohol solutions. Endogenous peroxidase was blocked by $0.3 \%$ hydrogen peroxide in methanol, at room temperature for 30 minutes. The samples were than treated by protease $(50 \mathrm{mg} / 100 \mathrm{ml} \mathrm{NaCl}-\mathrm{PBS})$ at $37^{\circ} \mathrm{C}$ for 5 minutes and than rinsed with ice-cold TRIS buffer (0.1M TBS, $\mathrm{pH} 7.8)$.

Preincubation in normal 10\% rats' sera in TBS was done prior to addition of primary antibodies at $4^{\circ} \mathrm{C}$ for $12-16$ hours. Primary monoclonal anti-cytokeratin antibodies were used (monoclonal Maus-Anti-Human Cytokeratin - clone LP-34, and M0717, Dako) and Maus-Anti-Human Cytokeratin-pan (1017390, Boehringer), both diluted 1:20 in TBS.

Secondary antibodies produced by rats against mouse $\lg G$ were diluted at 1:100 in TBS, a PAP complex was diluted 1:500 in TBS. Secondary and tertiary 
antibodies reacted at room temperature for 30 minutes. Between incubations the preparations were rinsed with TBS.

The visualization of the reaction was finally achieved by a 10 minute incubation in $0.05 \% 3.3$ diaminobenzidintetrahydrochloride (DAB) in $0.1 \mathrm{M}$ imidazole at $\mathrm{pH}$ 7.1. The contrast was obtained by Papanicolaou hematoxylin. The positive reaction was seen as a brown colored precipitate on cells with keratin filaments.

Pictures of the samples were taken on Olympus BX 41 microscope with a digital Olympus camedia C3030 camera.

\section{RESULTS}

After pathohistological examination, out of the 60 studied and operated bitches, in accordance to the WHO classification (Misdorp, 1999), 39 malignant tumors, 17 benign tumors, 3 hyperplastic-displastic alterations and one chronic inflammation of the mammary gland were diagnosed.

Amongst the benign neoplasms the most common were mixed tumors $(n=10)$ and adenomas $(n=6)$. Hyperplasia of the mammary gland was diagnosed in two bitches, while chronic steatitis, fibrosis and complex adenoma were diagnosed as sporadic.

Expression of cytokeratins in benign mixed tumors was found on epithelial and resting myoepithelial cells, while absent on mesenchymal cells in the cartilaginous and bone tissues (Figure 1).

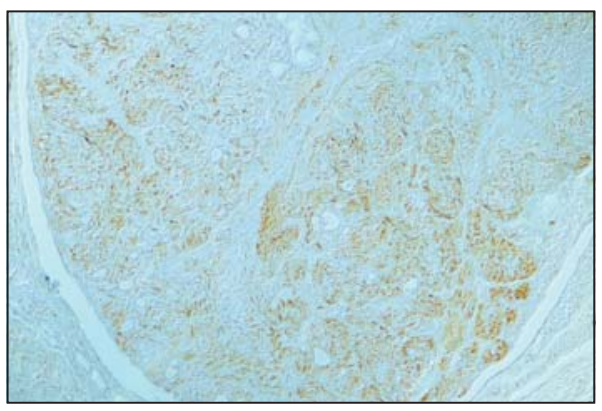

Figure 1. Benign mixed mammary gland tumor in a bitch (PAP, cytokeratin, 10x)

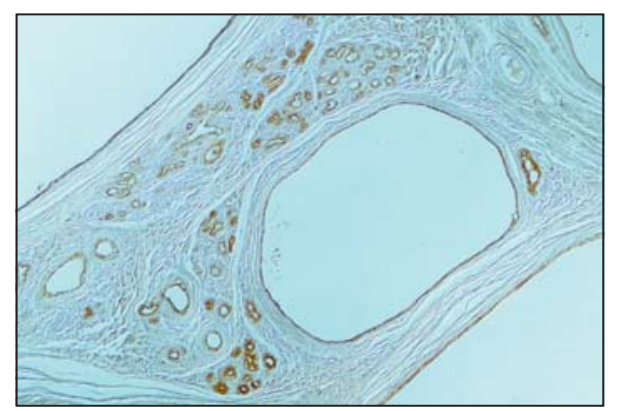

Figure 2. Mammary gland cystadenoma in a bitch (PAP, cytokeratin, 10x)

On all examined simple adenoma of the epithelial tissue expression of cytokeratins on neoplastic epithelial cells was evident. Resting myoepithelial cells in a simple myoepithelial adenoma were positive to cytokeratin, as well (Figure 2).

Out of the 39 examined malignant tumors simple adenocarcinoma was the most common $(n=17)$, followed by complex adenocarcinoma $(n=12)$, carcinoma in mixed tumors $(n=5)$, mucinous carcinoma $(n=3)$ and one of each fibrosarcoma and osteosarcoma. 
Simple carcinomas consist of only one type of neoplastic cells which in tumors with a solid growth are either epithelial cells from alveoli and canals (8 cases) or myoepithelial cells (3 cases). Neoplastic cells are found in the stroma, lymph and blood vessels. According to the predominant pathohistological picture and to the WHO criteria (1999) simple carcinoma are divided into tubulopapillar (4 tumors), solid (11 tumors) and anaplastic carcinoma (2 tumors).

Tubulopapillar adenocarcinoma is distinct by numerous tubular areas with cuboid cells or by a papillary structure covered by differentiated prismatic or cuboid epithelial cells. Cytokeratin in simple carcinoma with a tubulopapillary growth is diffusely expressed on prismatic and cuboid cells. The expression of cytokeratin in solid growth simple carcinoma is expressed densely and diffusely on neoplastic cells of the luminal epithelial cells, as well as on tumorous cells in the stroma and lymph and blood vessels. The proliferated neoplastic suprabasal myoepithelial cells in solid carcinomas are cytokeratin positive.

In the pathohistological picture of complex adenoarcinoma numerous noplastic epithelial and myoepithelial cells are present. They form tubular, papillar or solid structures. In the stroma spindele and/or stellate cells are commonly found, as well as sporadic plasma cells and lymphocytes. Tumor cells are irregularly differentiated; starting from pleomorph weakly differentiated ones to well-differentiated cuboid and prismatic cells present in some tumors. In the studied tumor samples, necrosis and inflammatory components were present in two, and neoplastic cells in lymph vessels were present in three complex adenocarcinoma. The expression of cytokeratin in complex carcinoma is on neoplastic epithelial cells in tubular or solid tumorous regions, as well as on resting, spindle and stellate myoepithelial tumor cells. Neoplastic cells in lymph and blood vessels are also cytokeratin positive.

Mixed tumor carcinomas contain epithelial and myoepithelial cells, as well as cells containing cartilaginous and/or bone tissue. In the cartilaginous lacunae a number of oval or stellate cells with eosinophilic cytoplasm are frequently found. The surrounding tissue is compressed and the multiplied myoepithelial cells are stellate or spindle shaped. Epithelial cells are of different grade of differentiation, polymorphous with small nuclei containing a number of nucleoli. Inflammation, hemorrhages and necrosis often accompany these mammary gland neoplasias in bitches. Immunohistochemical assays have shown the reactivity of epithelial, resting, spindle and stellate myoepithelial cells to cytokeratin. At the same time in malignant mixed tumors cytokeratin was not expressed on cartilage and bone tissue cells, nor on lymphocytes and plasma cells in the inflamed tissue (Figure 3).

Mucinous adenocarcinoma was diagnosed in three bitches older than 10 years. It is characterised by a high production of mucin, thus is classified as a secretory carcinoma. Neoplastic cells are stellate, triangular or have a dendritic shape. In the intercellular spaces basophilic mucin is present (Figure 4). Immunohistochemical studies of this tumor have shown wide areactive zones of intercellular mucinous substance, while neoplastic cells expressed cytokeratin. 


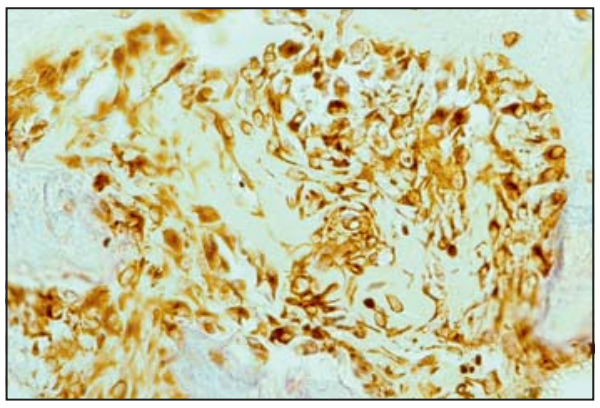

Figure 3. Carcinoma in a mixed mammary gland tumor (PAP, cytokeratin, 40x)

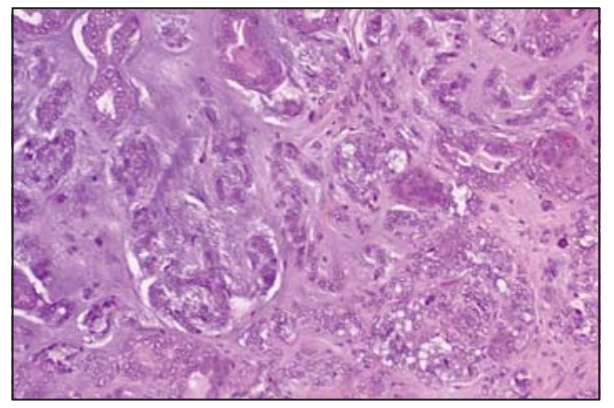

Figure 4. Mucinous mammary gland adenocarcinoma (HE, 20x)

\section{DISCUSSION}

The exceptionally multivariate histological make up, the role of growth factors and hormones, as well as the changes in the genetic material are the main set-backs for the correct interpretation of mammary gland tumors in bitches. Considering the extreme complexity none of the currently used histological classifications cannot entirely satisfy the needs of clinicians, pathologists and pet owners. Hence, great efforts are put into finding accurate and safe diagnostic and prognostic methods which would aid in the solution of the existing problems.

Within this study the analysis of mammary tumors in bitches was carried out in accordance to the latest histological WHO classification (Misdorp, 1999). The intention of the authors of the WHO classification was to give support to the formation of a unique nomenclature of mammary gland tumors in bitches. The WHO tumor classification gives a prognosis based upon the type and histological appearance of the tumor.

The ratio between malignant and benign tumors, the occurrence of different tumor types and hyperplasia identified on the studied samples are in accordance to the reports published by a number of authors (Bostock et al., 1986; Moulton 1990; Benjamin et al., 1999; Philibert, 2003; Zatloukal, 2005; Misdorp, 2002). The small variations between our data are probably due to the differences in pathohistological criteria, selection of material and a relatively small number of samples of individual tumor types.

Immunohistochemical methods and monoclonal antibodies were of key importance for an objective estimation of tumors. In our study a different expression of cytokeratins on some cell populations in benign and malignant neoplasms has been established.

Cytokeratin clone - LP 34 marks keratin and is expressed on the epithelium of the normal mammary gland duct and resting myoepithelial cells, on simple adenoma, fibroadenoma and hyperplastic mammary gland. On the other hand, in complex adenoma, benign mixed tumors, complex carcinoma, tumors with tubulopapillar and solid growth type cytokeratin is expressed on epithelial 
alveolar cells, as well as on the duct epithelium, resting myoepithelial cells, stellate and spindle myoepithelial cells in mammary gland heterogeneous immunophenotype carcinoma (Vos et al., 1993; Gartner et al., 1999). According to our research results in benign mixed tumors, cytokeratin is expressed on resting myoepithelial cells, while it is absent on mezenchyme cells, cartilage and bone tissue, lymphocytes and plasma cells present in the inflamed area.

Mixed tumors are characterised by morphologically different cells like cartilaginous, bone cells, adipocites and proliferated luminal epithelial cells (Gartner et al., 1999; Gama et al., 2003). In benign mixed tumors the histogenesis of mesenchyme elements, like bone and cartilage, is different and is interpreted as metaplasia of epithelial cells from connective tissue stroma or from basal epithelia i.e. myoepithelium (Destexhe et al., 1993; Griffey et al., 1993; Vos et al., 1993; Misdorp et al., 1999; Tateyama et al., 2001; Monteros et al., 2002; Gama et al., 2003). Myoepithelial cells present in mammary gland tumors in bitches can be classified into different morphological types: resting suprabasal, proliferating, spindle and stellate myoepithelial cells located in the interstitial space (Tateyama et al., 2001; Gama et al., 2003).

Cytokeratins are of primary importance in the histopathology of malignant tumors as they enable the differentiation of epithelium from mesenchyme and lymphoid cells (Schaafsma i Ramaekers, 1994; Martin et al., 1998; Nap et al., 2001; Mulas, 2004). They are expressed on the cells of bone marrow smears, as the first indicator of the dissemination of malignant epithelial cells (Martin et al., 1998; Borgen et al., 1998; Nap et al., 2001; Zuccari, 2004; Monteros, 2005). The expression of vimentin and cytokeratin in human mammary cancer cells is also related to the increased metastatic potential.

The possibility of early metastasis detection by immunohistochemical assays and labeling of tumor cells in the blood and lymph vessels is of great importance (Destexe, 1993). Immunohistochemical studies may indicate the origin of the tumor, specially the ones which are highly polymorph, when on the basis of pathomorphological and pathohistological findings, is difficult or impossible to accomplish an adequate classification and exact diagnosis.

Immunohistochemical assays exclude the possibility of subjective interpretation of histological findings, thus enabling an accurate diagnosis and classification, which are a must for a true prognosis and adequate clinical treatment of the affected animal.

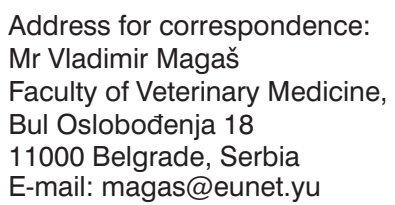

\section{REFERENCES}


2. Alenza $D$, Pena L, De Castillo $N$, Nieto $A, 2000$, Factors influencing the and prognosis of canine mammary tumours, J Small Anim Pract, 41, 287-91.

3. Alenza $D$, Tabanera E, Peña $L, 2001$, Inflammatory mammary carcinoma in dogs: 33 cases (19951999), J Am Vet Med Assoc, 219, 8, 1110-4.

4. Benjamin SA, Lee AC, Saunders WJ, 1999, Clasification and behavior of canine mammary epithelial neoplasms based on life-span observations in beagles, Vet Pathol, 36, 423-36.

5. Borgen E, Beiske K, Trachsel S, Nesland JM, Kvalheim G et al, 1998, Immunocytochemical detection of isolated epithelial cells in bone marrow. Non-specific staining and contribution by plasma cells directly reactive to alkaline phosphatase, $J$ Pathol, 185, 427-34.

6. Bostock $D E, 1986$, Canine and feline mammary neoplasms, Br Vet J, 142, 506-15.

7. Chang SC, Chang CC, Chang TJ, Wong ML, 2005, Prognostic factors associated with survival two years after surgery in dogs with malignant mammary tumors: 79 cases (1998-2002), J Am Vet Med Assoc, 227, 10, 1625-9.

8. Destexhe E, Lespagnard L, Degeyter M, Heymann R, Coignoul F, 1993, Immunohistochemical identification of myoepithelial, epithelial and connective tissue cells in canine mammary tumors, Vet Pathol, 30, 146-54.

9. Gama A, Alves A, Gartner F, Schmitt F, 2003, A Novel Myoepithelial Cell Marker in Canine Mammary Tissues, Vet Pathol, 40, 412-20.

10. Gartner F, Geraldes M, Cassali G, Rema A, Schmitt F, 1999, DNA measurement and immunohistochemical characterization of epithelial and mesenchymal cells in canine mixed mammary tumours: putative evidence for a common histogenisis, Vet $J, 158,39-47$.

11. Griffey SM, Madewell BR, Dairkee SH, Hunt JE, Naydan DK et al, 1993, Immunohistochemical reactivity of basal and luminal epithelium-specific cytokeratin antibodies within normal and neoplastic canine mammary glands, Vet Pathol, 30, 155-61.

12. Hellmen E, Lindgren A, 1989, The accuracy of cytology in diagnosis and DNA alalysis of canine mammary tumours, Comparative pathology of canine mamary tumours, J Comp Path, 101, 4, 443-50.

13. Jelesijević T, Jovanović $M$, Knežević M, Aleksić-Kovačević $S, 2003$, Quantitative and qualitative analysis of AgNOR in benign and malignant canine mammary gland tumors, Acta Vet, 53, 5-6, 353-60.

14. Martin VM, Siewert C, Scharl A, Harns T, Heinze $R$ et al, 1998, Immunomagnetic enrichment of disseminated epithelial tumor cells from peripheral blood by MACS, Exp Hematol, 26, 3, 25264.

15. Misdorp W, 2002, Tumors of the mammary gland. In: Tumors in Domestic Animals, ed. Meuten DJ, 4th ed., lowa State Press, Ames, IA, 575-606.

16. Misdorp W, Else RW, Hellmen E, Lipscomb TP, 1999, Histological classification of mammary tumors of the dog and the cat. Second Series. Volume VII. WHO International histological classification of tumors of domestic animals. AFIP, Washington DC.

17. Monteros A, Hellmen E, Ramirez GA, Herraez P, Rodriguez $F$ et al, 2003, Lipid-rich carcinomas of the mammary gland in seven dogs: clinicopathologic and immunohistochemical features, Vet Pathol, 40, 718-23.

18. Monteros A, Milla N, Ramýrez GA, Ordas J, Reymundo C et al. 2005, Expression of Maspin in Mammary Gland Tumors of the Dog, Vet Pathol, 42, 250-57.

19. Moulton JE, 1990, Tumors in domestic animals, Third edition, revised and expanded, University of California press.

20. Mulas J, Ordás J, Millán MY, Chacón F, De Lara M, Monteros A, Reymundo C, Jover A, 2004, Immunohistochemical expression of estrogen receptor beta in normal and tumoral canine mammary glands, Vet Pathol, 41, 3, 269-72.

21. Nap M, Wel van Th, Andres C, Bellanger $L$, Bodenmuller $H$ et al, 2001, Immunohistochemical Profiles of 30 Monoclonal Antibodies against Cytokeratins 8, 18 and 19, Tumor Biol, 22, 4-10.

22. Novosad CA, 2003, Principles of treatment for mammary gland tumors, Clin Tech Small Anim Pract, $18,2,107-9$. 
Acta Veterinaria (Beograd), Vol. 57. No. 1, 37-45, 2007.

23. Philibert JC, Snyder PW, Glickman N, Glickman LT, Knapp DW et al, 2003, Influence of host factors on survival in dogs with malignant mammary gland tumors, $J$ Vet Intern Med, 17, 1, 102-6.

24. Schaafsma HE, Ramaekers FC, 1994, Cytokeratin subtyping in normal and neoplastic epithelium: Basic principles and diagnostic applications, Pathol Ann, 29, 21-62.

25. Sorenmo KU, Shofer FS, Goldschmidt MH, 2000, Effect of spaying and timing of spaying on survival of dogs with mammary carcinoma, J Vet Intern Med, 14, 3, 266-70.

26. Tateyama S, Uchida K, Hidaka T, Hirao M, Yamaguchi R, 2001, Expression of bone morphogenetic protein-6 (BMP-6) in myoepithelial cells in canine mammary gland tumors, Vet Pathol, 38, 6, 703-9.

27. Vos JH, Ingh AM, Misdorp W, Molenbeek W, van Mil FN et al, 1993, Immunohistochemistry with keratin, vimentin, desmin and $\alpha$-smooth muscle actin monoclonal antibodies in canine mammary gland: malignant mammary tumours, Vet Quat, 15, 3, 96-102.

28. Zatloukal J, Lorenzová J, Tich F, Neâas A, Kecová $H$ et al, 2005, Breed and age as risk factors for canine mammary tumours, Acta Vet. Brno, 74, 103-9.

29. Zuccari DA, Santana AE, Cury PM, Cordeiro JA, 2004, Immunocytochemical study of Ki-67 as a prognostic marker in canine mammary neoplasia, Vet Clin Pathol, 33, 1, 23-8.

\title{
MORFOLOŠKA I IMUNOHISTOHEMIJSKA ISPITIVANJA HIRURŠKI ODSTRANJENIH TUMORA MLEČNE ŽLEZDE KUJA
}

\author{
MAGAŠ V, JOVIĆ S, NEŠIĆ V, BACETIĆ D i ALEKSIĆ-KOVAČEVIĆ SANJA
}

\section{SADRŽAJ}

U radu je izvršena procena maligniteta tumora mlečne žlezde kuja na osnovu kliničkog pregleda, makroskopskih i patohistoloških karateristika neoplazmi i ekspresije citokeratina. Ispitivanjem je bilo obuhvaćeno 60 kuja različite starosti, rase i reproduktivnog statusa, sa klinički uočljivim promenama na mlečnoj žlezdi. Posle kliničke opservacije, kod svih ispitivanih kuja izvršeno je hirurško odstranjivanje tumorskih proliferata, nakon čega su uzimani tkivni uzorci za patohistološku i imunohistohemijsku analizu. Tumori su klasifikovani prema najnovijoj preporuci WHO iz 1999. godine. Odnos malignih i benignih tumora je iznosio 1,9:1 u korist malignih alteracija. Najzastupljeniji maligni tumori su prosti adenokarcinomi (17 kuja), zatim kompleksni adenokarcinomi (12 kuja), iza kojih sledi 5 karcinoma u mešovitom tumoru, 3 mucinozna karcinoma i po jedan fibrosarkom i osteosarkom. Od benignih promena najzastupljeniji su benigni mešoviti tumori (10 kuja) i adenomi (6 kuja). Hiperplazija mlečne žlezde nađena je kod dve kuje, dok su hronični steatis, fibroza i kompleksni adenom dijagnostikovani u pojedinačnim slučajevima. Imunohistohemijskom metodom peroksidaza-antiperoksidaza, ustanovljena je ekspresija citokeratina na različitim ćelijama benignih i malignih neoplazmi. U prostim karcinomima, pozitivna reakcija nađena je u epitelu lumena kanalića i alveola, kao i na tumorskim ćelijama u stromi tumora, u limfnim i krvnim sudovima. U kompleksnim karcinomima, citokeratin je eksprimiran osim na epitelnim i na mirujućim, vretenastim i zvezdastim mioepitelnim ćelijama. 